\title{
A Modification of Cell-Lysis for High-Quality Intact RNA of Bacillus Subtilis Extracted From the Culture Under Different Physiological Stages
}

\section{Phetcharat Jaiaue}

Chulalongkorn University

Piroonporn Srimongkol

Chulalongkorn University

\section{Sitanan Thitiprasert}

Chulalongkorn University

\section{Somboon Tanasupawat}

Chulalongkorn University

\section{Benjamas Cheirsilp}

Prince of Songkla University - Hat Yai Campus: Prince of Songkla University

\section{Suttichai Assabumrungrat}

Chulalongkorn University

Nuttha Thongchul ( $\nabla$ Nuttha.T@chula.ac.th )

Chulalongkorn University https://orcid.org/0000-0002-8624-5441

\section{Original article}

Keywords: Bacillus subtilis, RNA Extraction Methods, Lysozyme Activity, Physiological Changes,

Sporulation, RNA Integrity

Posted Date: April 22nd, 2021

DOI: https://doi.org/10.21203/rs.3.rs-429777/v1

License: (1) (i) This work is licensed under a Creative Commons Attribution 4.0 International License.

Read Full License 


\section{Abstract}

High quality RNA products from bacterial cells are required for the molecular study. Sample preparation to acquire the high-quality RNA especially the Gram-positive bacteria like Bacillus sp., the model organism, remains a critical burden toward the integration of full molecular downstream analyses although several methods have been proposed including conventional or kit-based protocols. Those techniques were simply developed using the cell samples at certain growth stages unless some molecular studies require RNA samples gathered under different physiological stages of growth and process conditions. Herein, we developed the simple yet effective cell-lysis technique prior to RNA extraction by modifying the commercial kit-based protocols. Bacillus subtilis TL7-3 was used as the model organism in this study. Lysozyme loading $(20 \mathrm{mg} / \mathrm{mL})$ as well as the incubation time $(30 \mathrm{~min})$ and temperature $\left(37^{\circ} \mathrm{C}\right)$ was responsible for cell lysis and increased RNA concentration in the samples. Invert mixing rather than centrifugation and vortexing prevented RNA damage during protein precipitation by absolute ethanol. This was confirmed by the RNA Integrity Number (RIN) values greater than 8.0 of all RNA extracted from both vegetative cells and endospores of $B$. subtilis TL7-3. Additionally, absolute ethanol is preferable to our less-than-1-h protocol for protein precipitation as indicated from the higher ratios of $A_{260} / A_{280}$ and those of $A_{260} / A_{230}$ of the RNA products than 2.0 and 2.1, respectively. From the findings mentioned above, we successfully developed the modified RNA extraction protocol applicable for the intact cells of Gram-positive bacteria like Bacillus sp. at varied physiological and morphological stages.

\section{Introduction}

Bacillus sp. is the Gram-positive, spore forming bacterium. Unlike Gram-negative bacterium, Bacillus sp. lacks the outer membrane while it has a much thicker cell wall incorporated multilayers of peptidoglycan, teichoic acids, and other glycopolymers (Weidenmaier and Peschel 2008). Bacillus sp. is ubiquitous and readily adapts when exposed to environmental alteration. Under environmental stress, Bacillus sp. initiates various survival mechanisms. One of those is sporulation for generating a metabolically inactive dormant cell so called endospore which is able to survive under harsh conditions until the preferred growth conditions are restored (Tan and Ramamurthi 2014). Sporulation involves an asymmetric septation to produce a mother cell and the forespore. Engulfment of the smaller forespore by the larger mother cell leaves the forespore surrounded by two membrane where the spore peptidoglycan is synthesized within this intermembrane space. This spore peptidoglycan plays role in the attainment of spore core dehydration and; thus, becomes heat resistant (Meador-Parton and Popham 2000).

Bacillus sp. including Bacillus subtilis are typically used as the model organism for many molecular biology applications. Sample preparation process to acquire the high-quality nucleic acids (DNA, RNA) of Bacillus sp. remains a critical burden toward the integration of full analytical steps in the downstream applications although several methods have been proposed including conventional or kit-based protocols. Those protocols were mainly developed for certain point of the cultivation stages. However, Loading [MathJax]/jax/output/CommonHTML/jax.js ptome analysis require either DNA or RNA samples gathered 
under different physiological stages of growth and process conditions. This problem becomes more profound for Bacillus sp. since in bacterial population, sporulation does not occur homogeneously, but rather occurs in subpopulation (Tan and Ramamurthi 2014).

Cell wall disruption was reported to be the most tedious step as the integrity and rigidity depended on the structural unit of peptidoglycan (Vollmer et al. 2008). Peptidoglycan is composed of alternating units of $\mathrm{N}$-acetylglucosamine (NAG) and $\mathrm{N}$-acetylmuramic acid (NAM), linked by $\beta-(1,4)$ bonds (Primo et al. 2020). The mechanical cell wall disruption such as bead beating and ultrasonic methods require specialized laboratory equipment despite, they are simpler and more efficient than the enzyme-based technique (Hwang et al. 2011). Lysozyme and its disruptive effect on bacterial cell wall have been reported in several literatures. High quality of nucleic acids can be acquired with lysozyme treatment during cell-lysis especially in Gram-positive bacteria. Lysozyme facilitates cell wall disruption in combination with the lysis buffer (Amano and Williams 1984; Choi et al. 2012; Eber et al. 2018). In this study, we observed the effect of lysozyme on cell wall disruption. B. subtilis TL7-3 was selected for our study and the RNA yield obtained from the conventional cell-lysis was compared with those obtained from the kit-based protocols with lysozyme treatment. Lysozyme dosage and treatment time were also studied using our proposed protocol for improved RNA recovery yield.

Proteins, buffers, chemicals, detergents, enzymes, salts, and solvents possibly contaminated in the nucleic acid samples are strictly prohibited in the application in molecular diagnosis that requires PCR amplification (Hwang et al. 2011; Rantakokko-Jalava and Jalava 2002). Highly purified yet intact nucleic acid samples are therefore mandatory. Ethanol was reported for nucleic acid precipitation and washing (Fregel et al. 2010). Several factors, i.e., pH, ionic strength, purity of water, and the working steps, are claimed to be responsible for the obtained nucleic acid purity and integrity. By modifying the kit-based protocol, we successfully developed our in-house protocol for isolation of intact RNA from both the vegetative cells and spores of $B$. subtilis TL7-3. Our detailed protocols in comparison with the conventional methods and the 2 kit-based protocols were elucidated and reported in this work.

\section{Material And Methods}

\section{Bacterial strain}

The bacterial isolate TL7-3 screened from local Thai fermented food soybean by Professor Somboon Tanasupawat was used as a model spore producing bacterium for RNA extraction in this study. It was later identified by $16 \mathrm{~S}$ rRNA gene sequencing as Bacillus subtilis TL7-3. The 16S rRNA gene sequence of this isolate has been submitted to NCBI with the accession number MW820294.

\section{Cultivation method}

B. subtilis TL7-3 was subcultured onto GYP agar slants and incubated at $37^{\circ} \mathrm{C}$ for $24 \mathrm{~h}$. GYP (Glucose Yeast extract and Peptone) agar medium contained (per liter) $10 \mathrm{~g}$ glucose, $5 \mathrm{~g}$ yeast extract, $5 \mathrm{~g}$ peptone, 
$\mathrm{MgSO}_{4} \cdot 7 \mathrm{H}_{2} \mathrm{O}, 2 \mathrm{~g} \mathrm{MnSO}_{4} \cdot 5 \mathrm{H}_{2} \mathrm{O}, 2 \mathrm{~g} \mathrm{FeSO}_{4} \cdot 7 \mathrm{H}_{2} \mathrm{O}, 2 \mathrm{~g} \mathrm{NaCl}$. The $\mathrm{pH}$ of GYP medium was adjusted to 6.8 . After $24 \mathrm{~h}$, the cells were harvested and mixed with sterile $0.85 \% \mathrm{NaCl}$ solution. The optical density of the cell suspension was measured at $600 \mathrm{~nm}$ and it was adjusted to 25 by sterile $\mathrm{NaCl}$ solution to be used as an inoculum later.

B. subtilis TL7-3 was cultivated in GY medium containing (per liter) $60 \mathrm{~g}$ glucose, $3 \mathrm{~g}$ yeast extract, $4 \mathrm{~g}$ $\mathrm{NH}_{4} \mathrm{Cl}, 0.25 \mathrm{~g} \mathrm{KH}_{2} \mathrm{PO}_{4}, 0.25 \mathrm{~g} \mathrm{~K}_{2} \mathrm{HPO}_{4}, 5 \mathrm{~g} \mathrm{CaCO}_{3}$, and $10 \mathrm{~mL}$ salt solution. The cultivation was started by transferring $0.5 \mathrm{~mL}$ inoculum into $49.5 \mathrm{~mL} \mathrm{GY}$ medium. The culture was incubated at $37^{\circ} \mathrm{C}, 200 \mathrm{rpm}$ until the growth approached the stationary phase Culture broth samples were collected every $3 \mathrm{~h}$ for analyses.

\section{RNA recovery and purification}

Culture broth sample was centrifuged at $10,000 \mathrm{~g}, 4^{\circ} \mathrm{C}$ for $10 \mathrm{~min}$ and the supernatant was discarded. Cell pellet was stored at $-80^{\circ} \mathrm{C}$ until use. The cell pellet (approximately $10^{7} \mathrm{CFU} / \mathrm{mL}$ ) was washed in sterile deionized water for 3 times before use in RNA extraction process. The washed cell pellet was subjected to cell-lysis, the first step in RNA extraction process. 4 different cell-lysis methods were conducted, and the RNA recovery was investigated (Fig. 1). Lysozyme pretreatment was claimed to be responsible in this cell-lysis steps in several previous publications. In this study, we investigated this crucial step in cell-lysis by conducting lysis process with and without lysozyme pretreatment and the RNA extraction yield was compared. In Method 1 RNA extraction was performed without lysozyme pretreatment while in the other methods, lysozyme was introduced to the suspension of the cell pellet before adding the lysis buffer for cell breakage. Without lysozyme, cell pellets were subjected to cell wall denaturation using $350 \mu \mathrm{L}$ lysis buffer containing $\beta$-mercaptoethanol provided in RNeasy ${ }^{\circledR}$ mini kit; Qiagen, Germany). The suspension was vortexed until lysis. After that the suspension was centrifuged at $10,000 \mathrm{~g}$ for $2 \mathrm{~min}$ to remove the cell debris. The supernatant was then mixed with $600 \mu \mathrm{L} 70 \%$ ethanol. The solution was then inverted until well mixed before RNA purification in the RNeasy ${ }^{\circledR}$ mini spin column.

To improve RNA recovery yield, peptidoglycans and other glycol polymers were hydrolyzed by lysozyme at the first step. Here, we varied the lysozyme dose and the incubation time. In Method 2 following the protocol developed by Invitrogen (PureLink RNA® mini kit; Invitrogen, USA), we used the lysozyme solution containing $10 \mathrm{mM}$ Tris- $\mathrm{HCl}(\mathrm{pH} 8.0), 0.1 \mathrm{mM}$ EDTA, $0.5 \mu \mathrm{L} \mathrm{10 \%} \mathrm{SDS}$, and $10 \mathrm{mg} / \mathrm{mL}$ lysozyme. While in Method 3, we followed the protocol developed by Qiagen (RNeasy ${ }^{\circledR}$ mini kit; Qiagen, Germany). The lysozyme solution contained $30 \mathrm{mM}$ Tris-HCl (pH 8.0), $1 \mathrm{mM}$ EDTA, and $15 \mathrm{mg} / \mathrm{mL}$ lysozyme. Method 4, our protocol developed in this study, the lysozyme solution containing $20 \mathrm{mM}$ Tris $-\mathrm{HCl}(\mathrm{pH} 8.0)$, $2 \mathrm{mM}$ EDTA, $1.2 \%$ Triton X-100, and $20 \mathrm{mg} / \mathrm{mL}$ lysozyme was introduced in the first step in cell-lysis. All cell-lysis experiments were conducted in triplicate.

After cell-lysis, RNA was recovered and purified by loading the sample to RNeasy® mini kit (Qiagen, Germany). Later, the RNeasy mini spin column was loaded with $350 \mu \mathrm{L}$ washing buffer I (RW1). DNA denaturation was performed to eliminate the bound DNA on a silica-based membrane by treating with DNase I for 15 min at room temperature. Then, another $350 \mu \mathrm{L}$ RW1 was loaded into the column and the Loading [MathJax]/jax/output/CommonHTML/jax.js g, 15 s. After DNA denaturation, washing step was further 
performed by loading $500 \mu \mathrm{L}$ washing buffer II (RPE) into the column and the column was centrifuged at $10,000 \mathrm{~g}, 15 \mathrm{~s}$. This step was repeated by adding another $500 \mu \mathrm{L}$ RPE into the column and centrifugation was carried out at $10,000 \mathrm{~g}$ for $2 \mathrm{~min}$. The collecting tube was replaced by a new one before eluting the purified RNA by $30 \mu \mathrm{L}$ RNase-free water. The column was centrifuged at 10,000 g, 1 min to collect the RNA sample. The collected RNA sample was then used for detection in term of recovery yield and RNA product purity.

\section{Qualitative and quantitative RNA analysis}

Both concentration and purity of extracted RNA were examined from the ratios of the absorbencies at 260 $\mathrm{nm}$ and $280 \mathrm{~nm}$, and at $260 \mathrm{~nm}$ and $230 \mathrm{~nm}$ using Nanodrop Spectrophotometer (DS-11FX+, DeNovix®, USA). Additionally, isolation of intact RNA is essential for many techniques used in gene expression analysis. Those require RNA of extremely high integrity. We determined RNA integrity of the sample by evaluating from the $23 \mathrm{~S}$ and $16 \mathrm{~S}$ rRNA bands developed on $1 \%$ agarose gel with the presence of red fluorescent dyes using electrophoresis in TBE ( $45 \mathrm{mM}$ Tris-borate, $1 \mathrm{mM}$ EDTA) visualized under UV light. In addition, RNA Integrity Number (RIN) was determined using Agilent 2100 Bioanalyzer (Agilent Technologies, Palo Alto, CA, USA).

\section{Results}

\section{Growth and viability of B. subtilis TL7-3}

Figure 2 shows the growth profile of $B$. subtilis TL7-3 cultivated in GY medium during batch cultivation. The lag phase was not evident. In the first 3 h, B. subtilis TL7-3 grew at a slow rate as observed from a slowly increasing cell density $\left(\mathrm{OD}_{600}\right)$ in this early log stage. Later, the culture entered the mid log where the apparent growth rate was the highest. After $12 \mathrm{~h}$, the culture approached the late log stage before entering to the stationary stage at $15 \mathrm{~h}$. The fermentation was carried out until $24 \mathrm{~h}$ without the evidence of the death stage. Spores were slowly formed since the beginning of fermentation. After $6 \mathrm{~h}$, sporulation became obvious. At $15 \mathrm{~h}$, the total spore counts equaled the vegetative cell counts. Later, it was observed that the total number of spores were more than those of vegetative cells. The appearance of these metabolically dormant cells implied that the subpopulations entered sporulation in response to the metabolic regulation that relied on a series of feedback and feed-forward loops in the cell cycle development program. As the results, they could survive under unfavorable physical and chemical conditions (Meador-Parton and Popham 2000; Tan and Ramamurthi 2014).

It should be noted that similar profiles of cell density and total viable cell counts in term of $\mathrm{CFU} / \mathrm{mL}$ clearly stated that the samples used in RNA extraction and purification were from the intact cells.

\section{Lysozyme effect on RNA yield}

Gram-positive bacteria have a single lipid membrane surrounded by a cell wall incorporated a thick layer of peptidoglycan (Weidenmaier and Peschel 2008). Lysozyme is an enzyme that cleaves peptidoglycan in Loading [MathJax]/jax/output/CommonHTML/jax.js sis of $\beta-(1,4)$ linkages between $N$-acetylglucosamine (NAG) 
and $\mathrm{N}$-acetylmuramic acid (NAM) saccharides. Lysozyme is therefore responsible for cell lysis (Amano and Williams 1984; Choi et al. 2012). To promote the enabling denaturation of lysis buffer at plasma membrane, lysozyme was applied in this study. The disruptive effect of lysozyme on B. subtilis TL7-3 cell wall was observed from the RNA recovery yield. The enzyme concentration and incubation time were varied (Fig. 1). As expected, the lowest RNA yield was obtained from the RNA extraction process without lysozyme pretreatment. This indicated that the multiple coat layers comprising of peptidoglycan and other glycopolymers in the cell wall of B. subtilis TL7-3 hindered the transport of the lysis buffer; therefore, cell membrane denaturation process was incomplete, and eventually resulting in difficulties in transport of the cellular components throughout cytoplasmic membrane and cell wall (Eber et al. 2018).

Increasing lysozyme concentration (from $10 \mathrm{mg} / \mathrm{mL}$ (in Method 2) to $15 \mathrm{mg} / \mathrm{mL}$ (in Method 3) and 20 $\mathrm{mg} / \mathrm{mL}$ (in Method 4)) and incubation time (from $5 \mathrm{~min}$ (in Method 2) to $10 \mathrm{~min}$ (in Method 3) and 30 min (in Method 4)) enhanced RNA recovery (Table 1). Here, the action of lysozyme in breaking down the cell wall structure was clearly elucidated. This could further promote membrane denaturation process by the lysis buffer. Temperature was found to be responsible for promoting the action of lysozyme in hydrolysis of peptidoglycan. Unlike in Method 2 and Method 3, the incubation temperature was set at 37 ${ }^{\circ} \mathrm{C}$ during lysozyme pretreatment in Method 4. This temperature was claimed to be an optimal condition for lysozyme pretreatment (Hussain et al. 2015).

Table 1

Total RNA extracted from intact $B$. subtilis TL7-3 cell pellets collected during batch fermentation. $B$. subtilis TL7-3 cell pellets at $10^{7} \mathrm{CFU} / \mathrm{mL}$ were subjected to different cell-lysis methods followed by RNA purification using RNeasy® mini kit.

\begin{tabular}{|c|c|c|c|c|c|}
\hline \multirow{2}{*}{$\begin{array}{l}\text { Cell-lysis } \\
\text { method }\end{array}$} & \multicolumn{5}{|c|}{ RNA concentration $(n g / \mu L)$ at } \\
\hline & $3 \mathrm{~h}$ & $6 \mathrm{~h}$ & $9 \mathrm{~h}$ & $12 \mathrm{~h}$ & $15 \mathrm{~h}$ \\
\hline Method 1 & $32.90 \pm 6.09$ & $22.07 \pm 2.29$ & $26.26 \pm 2.56$ & $21.13 \pm 2.04$ & $18.24 \pm 1.02$ \\
\hline Method 2 & $566.30 \pm 6.36$ & $70.24 \pm 4.82$ & $75.72 \pm 2.66$ & $51.17 \pm 1.45$ & $46.59 \pm 7.70$ \\
\hline Method 3 & $1184.54 \pm 30.76$ & $617.84 \pm 12.52$ & $129.69 \pm 23.97$ & $56.11 \pm 11.20$ & $50.55 \pm 8.90$ \\
\hline $\begin{array}{l}\text { Method } 4 \\
\text { (this study) }\end{array}$ & $1875.04 \pm 25.85$ & $975.40 \pm 22.30$ & $727.16 \pm 23.51$ & $398.38 \pm 6.82$ & $346.89 \pm 36.41$ \\
\hline The value & mean $\pm S D(n$ & & & & \\
\hline
\end{tabular}

Bacterial growth stages and sporulation seemingly affected RNA extraction. Multiple coat layers of peptidoglycan and other glycopolymers were dynamically developed through the growth stages in response to environmental conditions such as availability of nutrients, changes of physical $\mathrm{pH}$ and temperature (Choi et al. 2012; Weidemaier and Peschel 2008). The highest RNA concentration especially during the late log and stationary stages obtained in Method 4 in comparison to the other 3 methods revealed that the effect of enzyme loading, and incubation time were more profound during sporulation Loading [MathJax]/jax/output/CommonHTML/jax.js ;igid as the coated layers protected the spore from 
enzymatic degradation by lysozyme, for example (Figs. 2 and 3) (Meador-Parton and Popham 2000; Tan and Ramamurthi 2014).

\section{Protein removal during cell-lysis}

Purification of intact RNA from samples is required in several molecular biology applications. Complete removal of cellular lipids and proteins including cellular proteases during cell-lysis prior to RNA purification can provide good results in their further uses (Hwang et al. 2011). The lysate obtained from 4 different cell-lysis methods was subjected to further RNA recovery and purification by loading the supernatant into the RNeasy mini spin column where other components in the lysate were not bound to the column and the DNA was denatured. RNA purity was determined using the absorbance ratios. An $A_{260} / A_{280}$ ratio of 1.8 for DNA and 2.0 for RNA indicates pure nucleic acid preparation, i.e., protein free (Wilfinger et al. 1997). Table 2 shows protein contamination in the RNA samples of $B$. subtilis TL7-3. The highest protein contamination in the RNA samples was observed from the lysates obtained by Method 1 . With the lowest nucleic acid contents released from the samples as a result of incomplete cell-lysis (Table 1) and the one-step precipitation and washing of nucleic acids using $70 \%$ ethanol, this could carry over the contaminated proteins into the mini spin column where RNA purification was acquired (Fregel et al. 2010; Zeugin and Hartley 1985). Therefore, the poor $A_{260} / A_{280}$ ratios were obtained.

Table 2

Protein contamination in total RNA samples extracted by different cell-lysis method followed by RNA purification using RNeasy ${ }^{\circledR}$ mini kit. $B$. subtilis TL7-3 was cultivated in GY medium. The fermentation broth was collected during the batch cultivation and the intact cell pellets at $10^{7} \mathrm{CFU} / \mathrm{mL}$ were subjected to RNA extraction and purification.

\begin{tabular}{|c|c|c|c|c|c|}
\hline \multirow[t]{2}{*}{ Cell-lysis method } & \multicolumn{5}{|c|}{$\mathrm{A}_{260} / \mathrm{A}_{280}$ ratio } \\
\hline & $3 \mathrm{~h}$ & $6 \mathrm{~h}$ & $9 \mathrm{~h}$ & $12 \mathrm{~h}$ & $15 \mathrm{~h}$ \\
\hline Method 1 & $3.45 \pm 0.21$ & $1.57 \pm 0.31$ & $2.11 \pm 0.11$ & $1.25 \pm 0.14$ & $1.13 \pm 0.14$ \\
\hline Method 2 & $2.77 \pm 0.18$ & $2.74 \pm 0.08$ & $2.57 \pm 0.25$ & $3.17 \pm 0.16$ & $2.77 \pm 0.06$ \\
\hline Method 3 & $2.09 \pm 0.02$ & $2.08 \pm 0.01$ & $2.08 \pm 0.03$ & $1.78 \pm 0.07$ & $1.40 \pm 0.38$ \\
\hline $\begin{array}{l}\text { Method } 4 \\
\text { (this study) }\end{array}$ & $2.10 \pm 0.02$ & $2.10 \pm 0.04$ & $2.07 \pm 0.02$ & $2.09 \pm 0.01$ & $2.10 \pm 0.05$ \\
\hline
\end{tabular}

With the lysozyme treatment, a lower protein contamination was observed in the RNA samples obtained from cell-lysis Method 2, 3, and 4. This could be explained by the significantly improved RNA yields obtained from these 3 methods in comparison to those in Method 1. As a result, the improved $A_{260} / A_{280}$ ratios were achieved. The highest $A_{260} / A_{280}$ ratios were obtained from the RNA samples prepared by Method 2. The purity of RNA samples obtained from Method 3 and Method 4 are similar during the early Loading [MathJax]/jax/output/CommonHTML/jax.js 
and mid-log stages of growth. When growth entered the late log and stationary stages, RNA purity of the samples prepared by Method 3 was decreased as observed from $A_{260} / A_{280}$ lower than 2.00. The lower RNA purity during the late stage of growth when sporulation became pronounced as a consequence of the lower RNA yield due to incomplete cell disruption. Although Proteinase K was added during 10-min lysozyme treatment to facilitate protein denaturation, this indicated that the lysis conditions in Method 3 were not applicable for rigid cell wall disruption like cells at late stage of growth or during sporulation.

Several studies reported different protocols for several microbes to eliminate proteins from the nucleic acid samples. The most common technique for concentration and purification of nucleic acids is precipitation with absolute ethanol while $70 \%$ ethanol is for washing (Fregel et al. 2010). Here, we found that precipitation of nucleic acids with both $70 \%$ ethanol and absolute ethanol after lysozyme treatment could sufficiently eliminate proteins in the nucleic acid samples before loading the samples for RNA purification in the mini spin column where DNA denaturation occurred by treating with DNase I.

\section{$A_{260} / A_{230}$ as a sensitive indicator of contaminants}

While $A_{260} / A_{280}$ reveals the type of nucleic acid present (dsDNA or RNA) and provides a rough indication of protein contamination, the $A_{260} / A_{230}$ is the sensitive indicator of contaminants that absorbs at 230 $\mathrm{nm}$. These contaminants including chaotropic salts such as guanidine thiocyanate (GTC) and guanidine hydrochloride (GuHCl), EDTA, non-ionic detergents like Triton X-100 and Tween 20, proteins, and phenol are several more than those absorbing at $280 \mathrm{~nm}$. Polysaccharides or free-floating solid particles like silica fibers also absorb at $230 \mathrm{~nm}$. Table 3 depicts the RNA samples contaminated by the chemicals absorbing at $230 \mathrm{~nm}$ by the ratios of $A_{260} / A_{230}$. Typically, $A_{260} / A_{230}$ ratio of 2.1-2.3 was reported for pure RNA. Using $70 \%$ ethanol for simultaneously precipitating nucleic acids and washing during cell-lysis could only eliminate some proteins but buffer contaminants remained. As a result, the $A_{260} / A_{230}$ ratios of RNA samples obtained by Method 1 and Method 2 were low. On the other hand, using absolute ethanol gave a better result in removal of contaminants absorbing at $230 \mathrm{~nm}$ as observed from higher ratios of $A_{260} / A_{230}$ of the RNA samples obtained by Method 3 and Method 4 . It was noticed that the significant decrease in $A_{260} / A_{230}$ ratios of the RNA samples at $12 \mathrm{~h}$ and $15 \mathrm{~h}$ obtained by Method 3 was due to failure in cell disruption when the cell wall became more rigid after entering the late stage of growth and sporulation. 
Table 3

Extracted RNA samples of $B$. subtilis TL7-3 contaminated by salts, non-ionic detergents, proteins, and phenol. B. subtilis TL7-3 was cultivated in GY medium during batch cultivation. Cell pellets at $10^{7} \mathrm{CFU} / \mathrm{mL}$ collected during batch cultivation in GY medium were subjected to RNA extraction using different cell-lysis method followed by purification using RNeasy ${ }^{\circledR}$ mini kit.

\begin{tabular}{|c|c|c|c|c|c|}
\hline \multirow[t]{2}{*}{ Cell-lysis method } & \multicolumn{5}{|c|}{$A_{260} / A_{230}$ ratio } \\
\hline & $3 \mathrm{~h}$ & $6 \mathrm{~h}$ & $9 \mathrm{~h}$ & $12 \mathrm{~h}$ & $15 \mathrm{~h}$ \\
\hline Method 1 & $0.09 \pm 0.06$ & $0.07 \pm 0.04$ & $0.17 \pm 0.10$ & $0.53 \pm 0.21$ & $0.06 \pm 0.03$ \\
\hline Method 2 & $0.13 \pm 0.05$ & $0.19 \pm 0.05$ & $0.26 \pm 0.03$ & $0.35 \pm 0.07$ & $0.55 \pm 0.40$ \\
\hline Method 3 & $2.40 \pm 0.04$ & $2.26 \pm 0.04$ & $2.35 \pm 0.09$ & $0.56 \pm 0.02$ & $0.28 \pm 0.04$ \\
\hline $\begin{array}{l}\text { Method } 4 \\
\text { (this study) }\end{array}$ & $2.38 \pm 0.04$ & $2.37 \pm 0.03$ & $2.38 \pm 0.04$ & $2.13 \pm 0.04$ & $2.36 \pm 0.07$ \\
\hline The values Indl & $\pm \mathrm{S}$ & =3). & & & \\
\hline
\end{tabular}

As aforementioned, the ratios of $A_{260} / A_{280}$ and those of $A_{260} / A_{230}$ of the RNA products purified using Method 4 are higher than 2.0 and 2.1, respectively, for all cell samples in regardless of their physiological stages (vegetative cells vs. spores). Therefore, the RNA samples obtained by our modified method (Method 4) are considered to be clean and suitable for use in the downstream applications.

\section{RIN number indicating RNA integrity}

Not only concentration and purity are required, but integrity of RNA samples is also necessary. The RIN was evaluated for validation of the intact RNA. RIN values indicate overall RNA integrity by determining the ribosomal 23S/16S ratio, with a score from 1 (degraded RNA) to 10 (intact RNA). In gene expression study, RIN value greater than 8.0 is essential for successful downstream applications (Hampton-Marcell et al. 2013; Hitzemann et al. 2014). Figures 4-7 show the electropherograms of RNA extracted using 4 different cell-lysis methods. We observed the low RIN values of all RNA extracted from cell samples collected during different stages when the cells were subjected to lysis protocol using Method 1 (the highest obtained RIN value was only 4.80) and Method 2 (the highest obtained RIN values was 6.80) (Figs. 4-5). The low RNA concentration of the samples extracted by Method 1 was believed to be responsible for the low RIN values. While rigorous mixing by vortexing during nucleic acid precipitation was claimed to cause RNA degradation during cell-lysis protocol using Method 2. Unlike those of Method 1 and Method 2, the obtained electropherograms of the RNA samples obtained from Method 3 and Method 4 showed clear peaks, corresponding to $16 \mathrm{~S}$ rRNA and 23S rRNA as the evidence of low RNA degradation (Figs. 6-7). The resulting RIN values greater than 8.0 were acquired in all cell samples collected throughout the fermentation indicating that gently inverting instead of vortexing helped prevent RNA damage during nucleic acid purification step. Thus, this confirmed the great RNA integrity for further downstream usaces. Nevertheless. it should be noted that the RNA yield (Table 1) and purity (Tables 2-3) Loading [MathJax]/jax/output/CommonHTML/jax.js 
of the cell samples extracted by Method 3 at late stage of growth were significantly low when sporulation became profound. Thus, RNA extraction by Method 3 is not suitable for cell samples with the high content of endospores. From Tables 1-3 and Fig. 7, we can claim that our modified cell-lysis protocol developed in this study could enhance RNA yield as well as maintaining the integrity of the RNA samples.

\section{Discussion}

Extraction and purification of RNA in Gram-positive bacteria like Bacillus sp. usually suffers from the low product yield. Although the lysozyme pretreatment together with Trizol reagent technique was claimed to promote cell-lysis; therefore, enhanced RNA extraction that yielded high RNA quality, this protocol is seemingly a time-consuming process (approximately $4 \mathrm{~h}$ ) and harsh reagents (phenol-chloroform) are required during RNA recovery (Eber et al., 2018). While there is no optimal RNA recovery from intact cells for all morphological and physiological stages, a short general protocol yet efficiently providing high quality RNA product is preferable to the time-consuming standard. Here we reported a short-time, simple technique that allowed proper cell lysis for both vegetative cells and endospores of $B$. subtilis TL7-3, the model strain, prior to RNA extraction using the RNeasy ${ }^{\circledR}$ mini kit. Our less-than-1-h modified protocol with no harsh reagents yielded high quality RNA products by using lysozyme pretreatment at proper loading ratio combined with protein precipitation by absolute ethanol at the suitable temperature and time. With proper optimization on lysozyme loading $(20 \mathrm{mg} / \mathrm{mL})$ and pretreatment temperature $\left(37^{\circ} \mathrm{C}\right)$ and time (30 $\mathrm{min})$, this promoted the breakage of $b-(1,4)$ bonds and therefore enhanced the cell disruption process by the lysis buffer of cell samples collected at different physiological and morphological stages. The complete cell-lysis yielded high RNA concentration and subsequently allowed effective protein precipitation by absolute ethanol without uses of Proteinase $\mathrm{K}$ and any reagents to protect RNA products. This resulted in low impurities remained in the RNA products as observed from the high values of $A_{260} / A_{280}$ and $A_{260} / A_{230}$ ratios. Not only the high RNA purity could be acquired, but the high RIN values also indicated the intact RNA products were obtained by our simple yet effective modified protocol. By this, we successfully obtained a large quantity of RNA products with the sufficiently high purity and integrity that could be applicable for further molecular downstream applications.

\section{Abbreviations}

RIN: RNA Integrity Number

\section{Declarations}

\section{Acknowledgments}

The authors would like to acknowledge National Security and Dual-Use Technology Center, National Science and Technology Development Agency (NSTDA), for supporting our study. PJ is the recipient of the Development and Promotion of Science and Technology Talents Project (DPST) provided by Thailand Research Fund. 


\section{Funding}

This study was partially funded by National Research Council of Thailand, Research Chair Grant provided by National Science and Technology Development Agency (NSTDA), and Thailand Research Fund (Grant No. RTA6280014).

\section{Authors' contributions}

NT conceived and designed the research; PJ conducted the experiments with the assistance from PS and ST. NT and ST supervised the research. BC and SS provided the consultation in manuscript preparation. NT and PJ wrote the manuscript. All authors read and approved the manuscript.

\section{Availability of data and materials}

The 16S rRNA gene sequence of $B$. subtilis TL7-3 has been submitted to NCBI with accession number MW820294.

\section{Ethics approval and consent to participate}

This article does not contain any studies with human participants or animals performed by any of the authors.

\section{Consent for publication}

All authors have provided consent for this publication.

\section{Competing interests}

All the authors declare that they have no conflict of interest.

\section{References}

Amano K-I, Williams JC (1984) Sensitivity of Coxiella burnetiid peptidoglycan to lysozyme hydrolysis and correlation of Sacculus rigidity with peptidoglycan-associated proteins. J Bacteriol 160(3):989-993

Choi Y, Moody IS, Sims PC, Hunt SR (2012) Single-molecule dynamics of lysozyme processing distinguishes linear and cross-linked peptidoglycan substrates. J Am Chem Soc 134:2032-2035

Eber V-R, Cuauhtemoc I-G, Sergio dIS-V (2018) Extraction of high-quality RNA from Bacillus subtilis with a lysozyme pretreatment followed by the Trizol method. J Microbiol Methods 147:14-16

Fregel R, Gonzalez A, Cabrera VM (2010) Improved ethanol precipitation of DNA. Electrophoresis 31:13501352 
Glasel JA (1995) Validity of nucleic acid purities monitored by $260 \mathrm{~nm} / 280 \mathrm{~nm}$ absorbance ratios. Biotechniques 18:62-63.

Hampton-Marcell JT, Moormann SM, Owens SM, Gilbert JA (2013) Preparation and metatranscriptomic analyses of host-microbe systems. Methods Enzymol 531:169-185

Hitzemann R, Darakjian P, Walter N, lancu OD, Searles R, McWeeney S (2014) Introduction to sequencing the brain transcriptome. Int Rev Neurobiol 116:1-19

Hussain M, Zahoor T, Anjum FM, Shahid M, Saeed F (2015) Isolation and characterization of buffalo milk lysozyme. Int J Food Prop 18:1288-1297

Hwang K-Y, Kwon SH, Jung S-O, Lim H-K, Jung W-J, Park C-S, Kim J-H, Suh K-Y, Huh N, (2011) Miniaturized bead-beating device to automate full DNA sample preparation processes for Gram-positive bacteria. Lab Chip 11:3649-3655

Meador-Parton J, Popham DL (2000) Structural analysis of Bacillus subtilis spore peptidoglycan during sporulation. J Bacteriol 182(16):4491-4499

Primo ED, Otero LH, Ruiz F, Klinke S, Giordano W (2018) The disruptive effect of lysozyme on the bacterial cell wall explored by an in-Silico structural outlook. Biochem Mol Biol Edu 46(1):83-90

Rantakokko-Jalava K, Jalava J (2002) Optimal DNA isolation method for detection of bacteria in clinical specimens by broad-range PCR. J Clin Microbiol 40(11):4211-4217

Tan IS, Ramamurthi KS (2014) Spore formation in Bacillus subtilis. Environ Microbiol Rep 6:212-225

Vollmer W, Blanot D, de Pedro MA (2008) Peptidoglycan structure and architecture. FEMS Microbiol Rev 32:149-167

Weidenmaier C, Peschel A (2008) Teichoic acids and related cell-wall glycopolymers in Gram-positive physiology and host interactions. Nat Rev Microbiol 6:276-286

Wilfinger WW, Mackey K, Chomczynski P (1997) Effect of pH and ionic strength on the spectrophotometric assessment of nucleic acid purity. Biotechniques 22:474-481

Zeugin JA, Hartley JL (1985) Ethanol precipitation of DNA. Focus 7:1-2

\section{Figures}




\begin{tabular}{|c|c|c|c|}
\hline Without lysozyme pretreatment & & With lysozyme pretreatment & \\
\hline $\begin{array}{l}\text { Cell pellet } \\
\text { Add } 350 \mu \mathrm{L} \text { lysis buffer } \\
\text { containing } \beta \text {-mercaptoethanol } \\
\text { Load to mini spin column }\end{array}$ & $\begin{array}{l}\text { Add } 100 \mu \mathrm{L} \text { lysozyme solution and } \\
\text { Incubate } 5 \text { min at room temperature } \\
\text { Add } 600 \mu \mathrm{L} 70 \% \text { ethanol } \\
\text { Load to mini spin column } \\
\text { containing } \beta \text {-mercaptoethanol } \\
\text { Collect supernatant } \\
\text { Method } 2 \\
\text { Vortex }\end{array}$ & 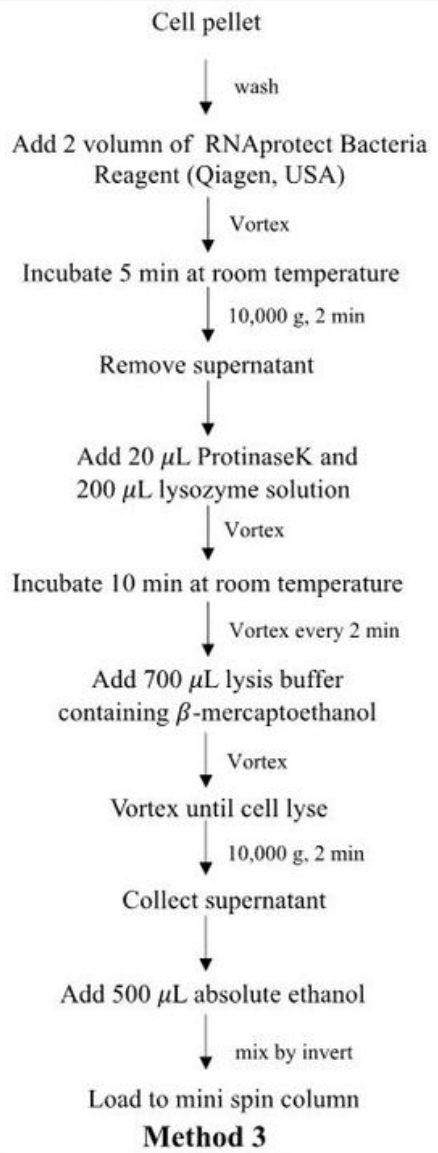 & $\begin{array}{l}\text { Add } 200 \mu \mathrm{L} \text { lysozyme solution } \\
\text { Incubate at } 37^{\circ} \mathrm{C} \text { for } 30 \mathrm{~min} \\
\text { Add } 700 \mu \mathrm{L} \text { lysis buffer } \\
\text { containing } \beta \text {-mercaptoethanol } \\
\text { absolute ethanol } \\
\text { Coad to mini spin column } 20 \text { times (gentle) } \\
\text { Vortex } \\
\text { Co, } 500,000 \mathrm{~g}, 2 \mathrm{~min}\end{array}$ \\
\hline
\end{tabular}

\section{Figure 1}

Process modification during cell-lysis steps in RNA extraction. In Method 1, the protocols provided by quick RNA extraction of RNeasy ${ }^{\circledR}$ mini kit was conducted. In Method 2, the modified Invitrogen protocol was conducted for cell-lysis. Cell-lysis in Method 3 was conducted using bacterial RNA extraction protocol of RNeasy ${ }^{\circledR}$ mini kit. Method 4 was the lysis protocol developed in this study. 


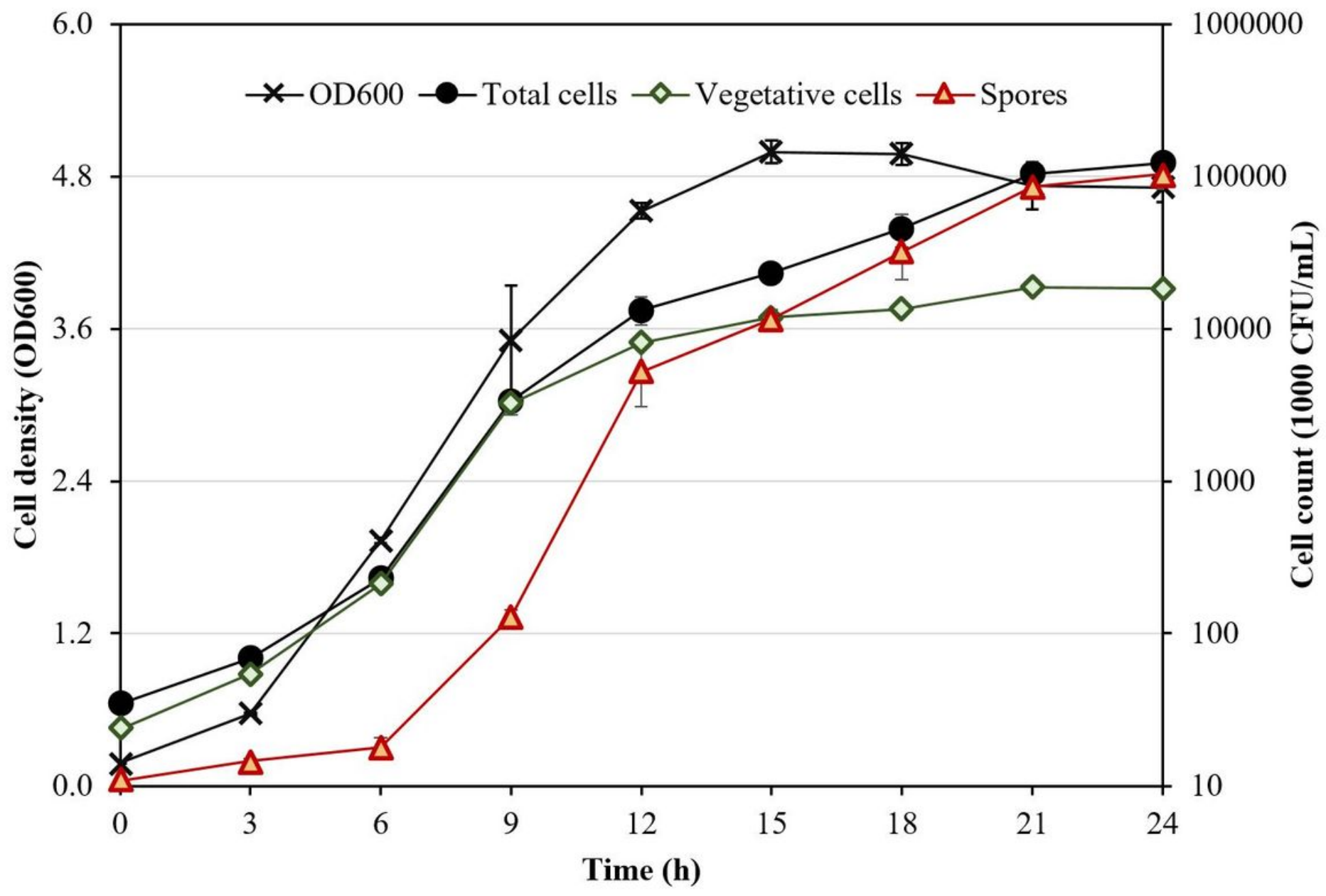

Figure 2

Growth kinetics of B. subtilis TL7-3 grown in GY medium at $37^{\circ} \mathrm{C}$. Shown are the optical density of the fermentation broth at $600 \mathrm{~nm}$ and colony counting of intact cells. Error bars indicate the standard deviation (SD) of the mean value $(n=3)$. 

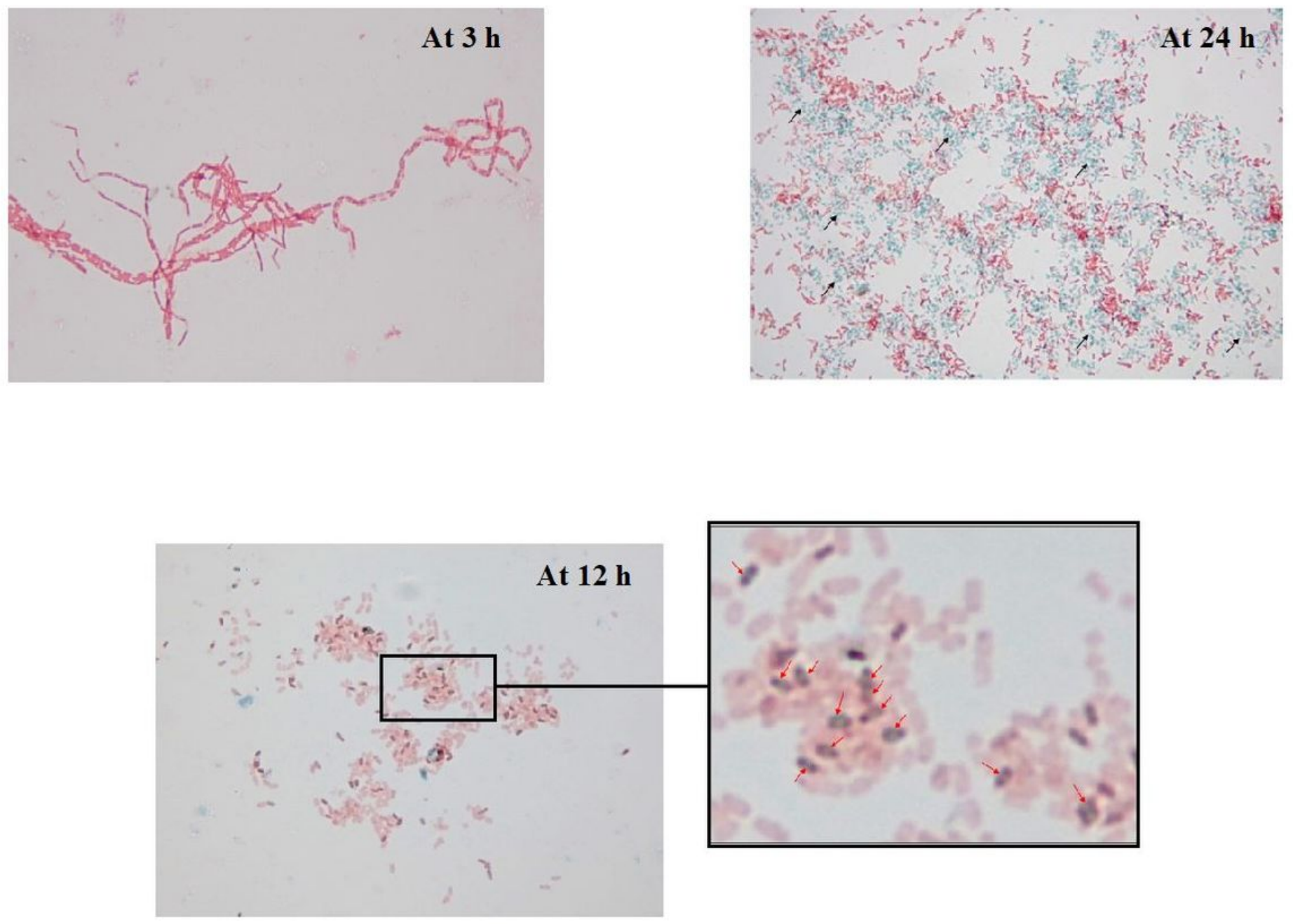

\section{Figure 3}

Cell morphology of B. subtilis TL7-3 under different physiological stages. Cell samples were collected during the fermentation. The endospores (appeared in green) were stained by Malachite Green while Safranin $O$ was used as a counterstain to dye the vegetative cells (appeared in red). 

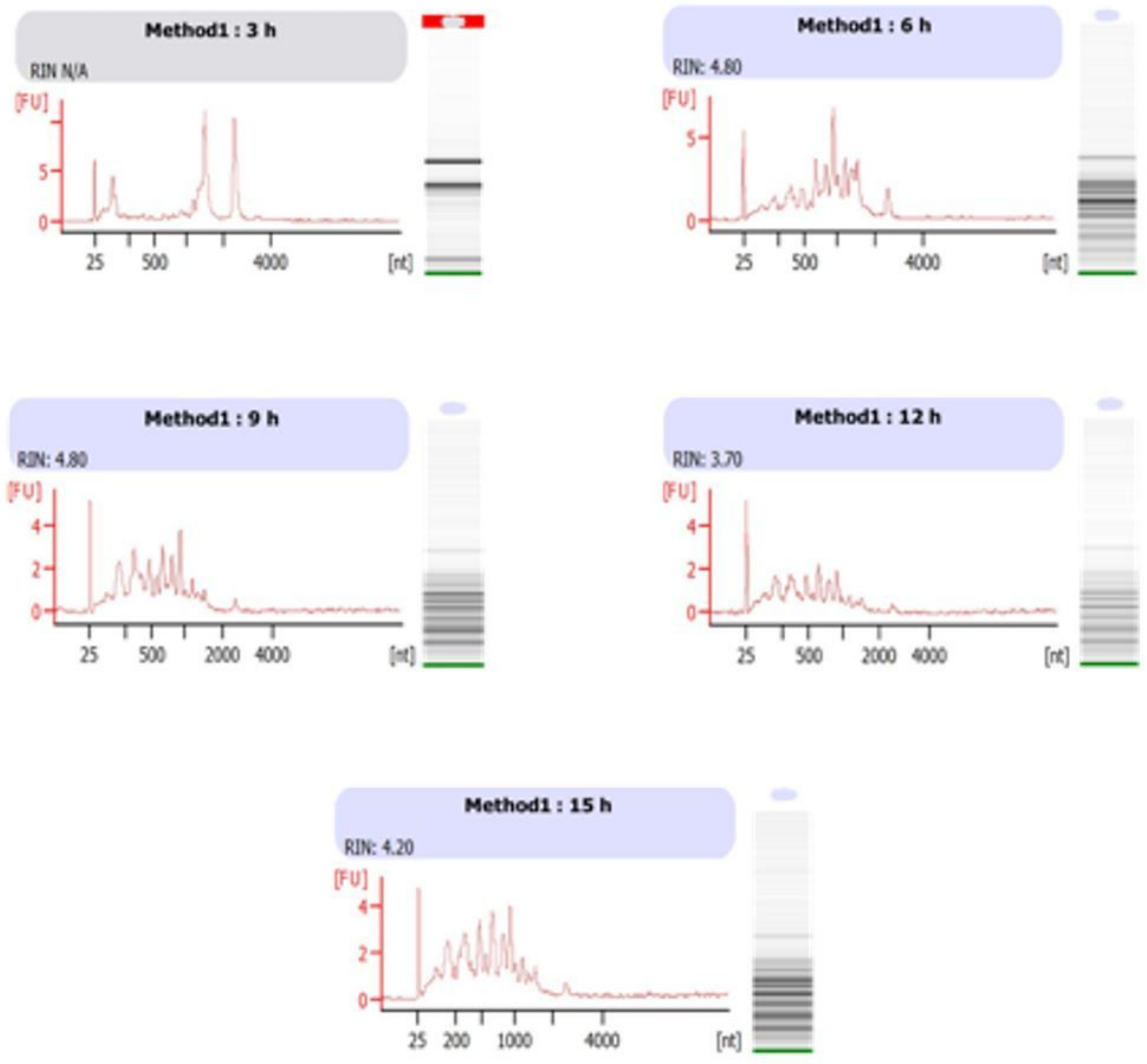

\section{Figure 4}

Electropherograms of RNA of B. subtilis TL7-3 under different growth stages using Method 1 during celllysis. 


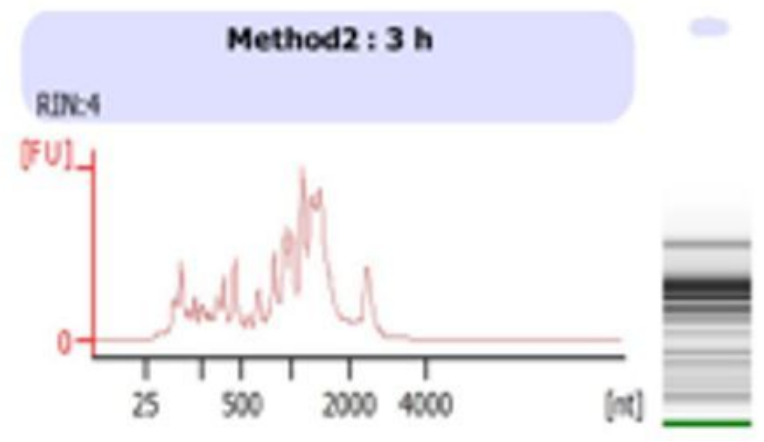

Method2: $6 \mathrm{~h}$

RIN: 6.50
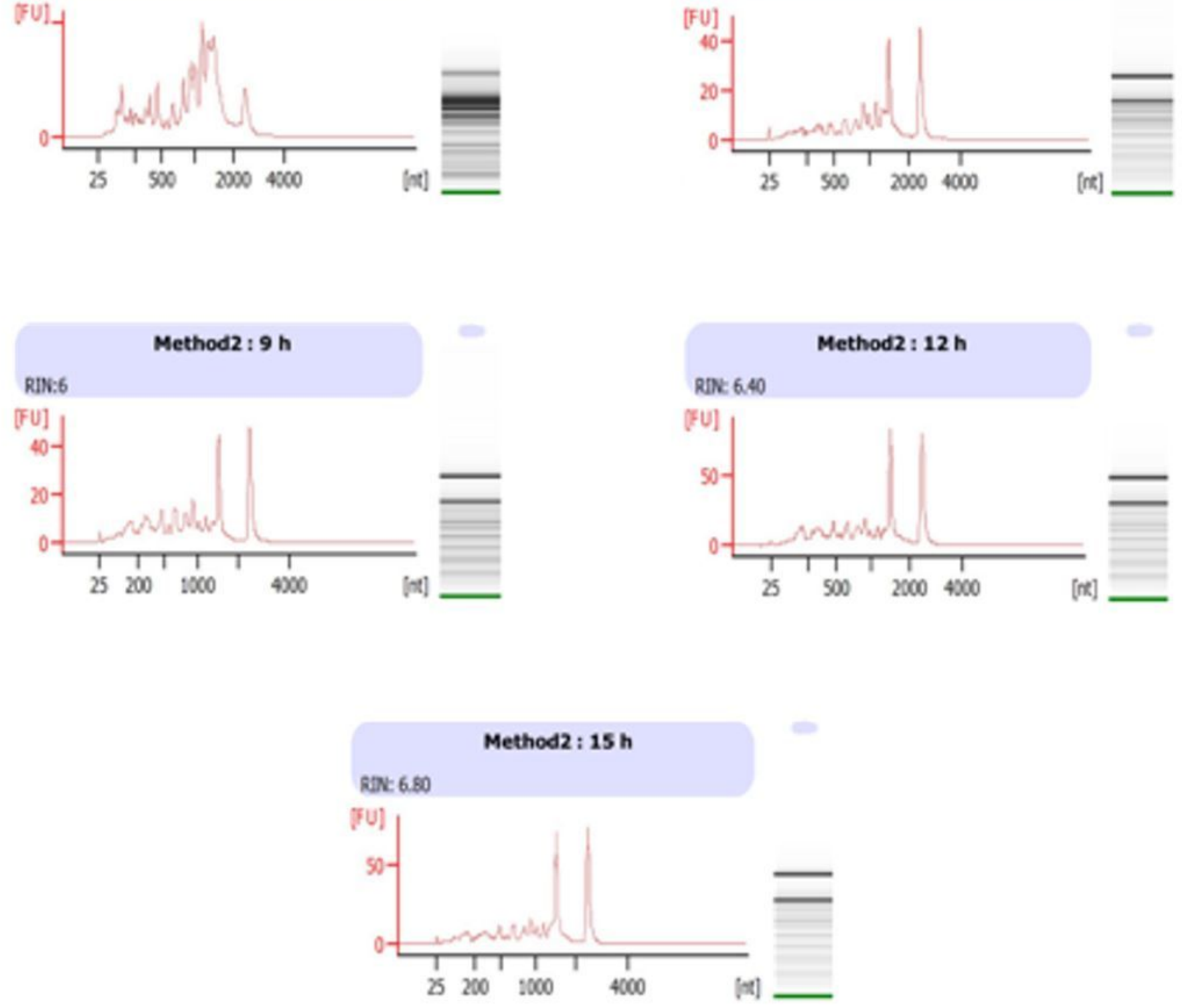

Figure 5

Electropherograms of RNA of B. subtilis TL7-3 under different growth stages using Method 2 during celllysis. 

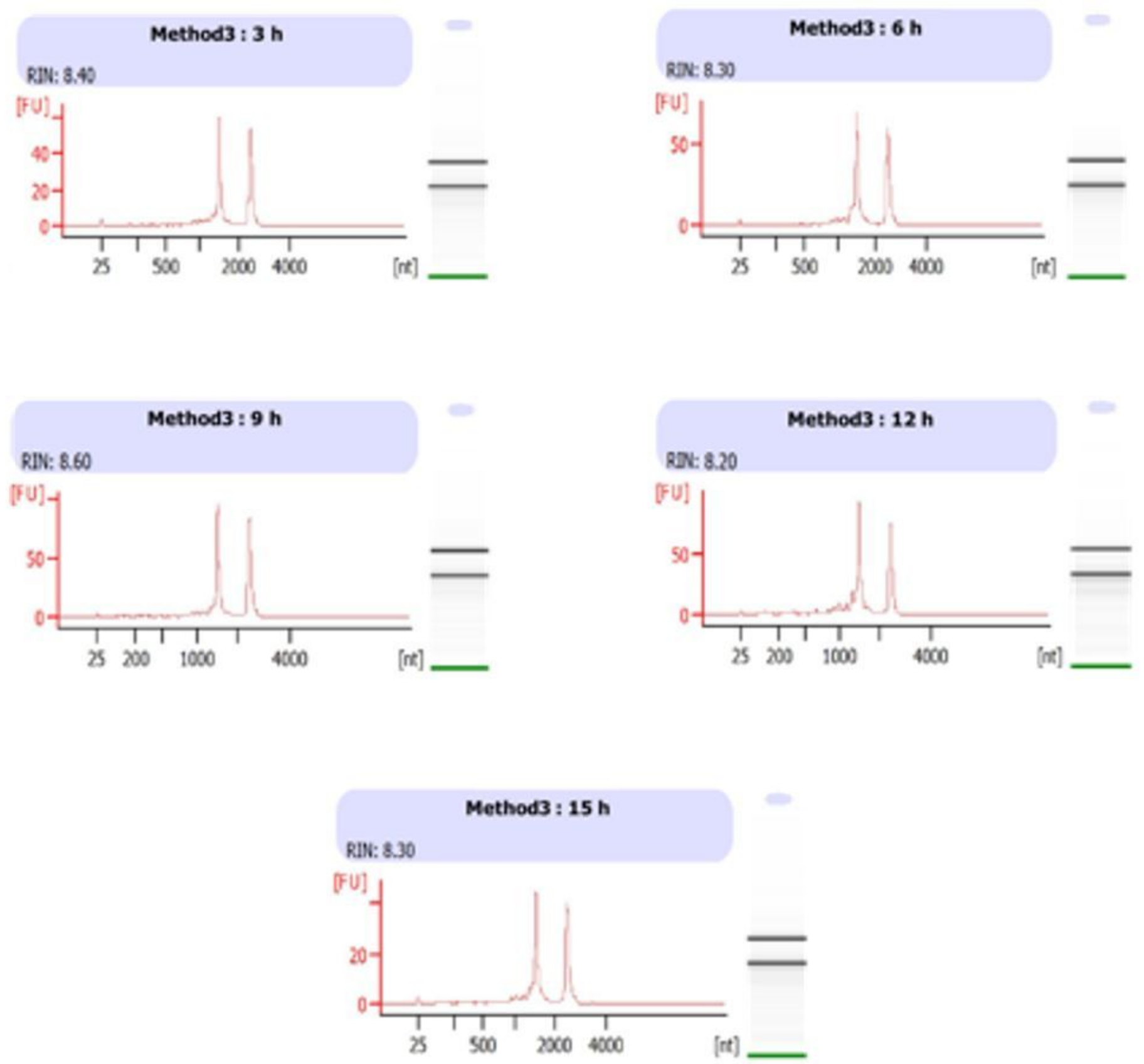

Figure 6

Electropherograms of RNA of B. subtilis TL7-3 under different growth stages using Method 3 during celllysis. 


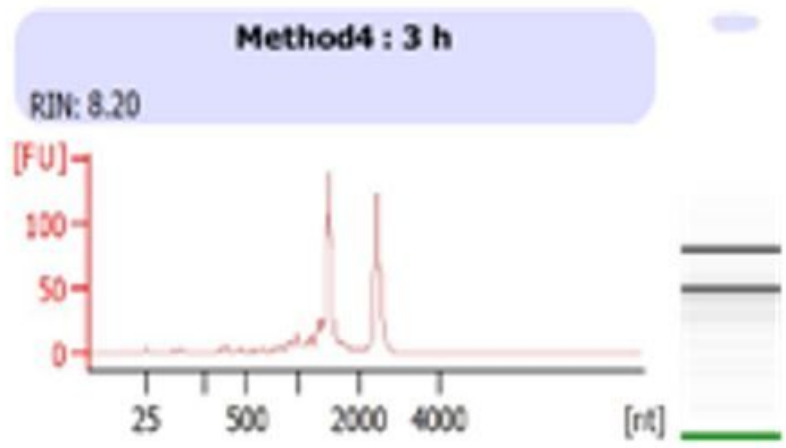

Method4: $6 \mathrm{~h}$

ADN: 8.42

[FU]

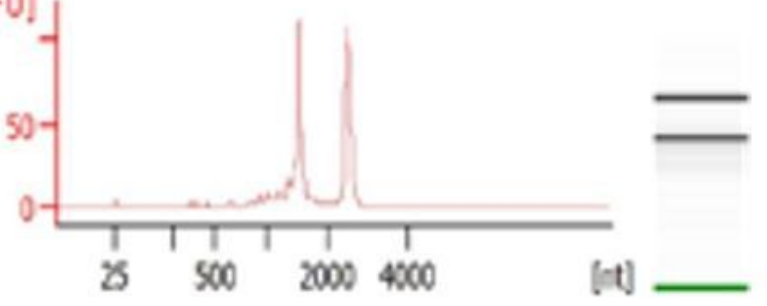

Method4: $12 \mathrm{~h}$

REV: 8.40

(FU)

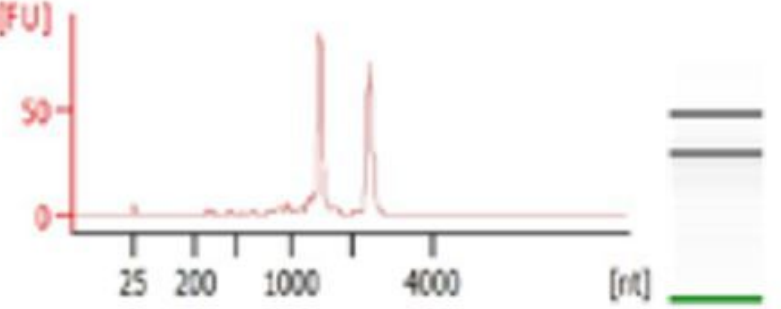

Figure 7

Method4: $15 \mathrm{~h}$

RDN: 8.70

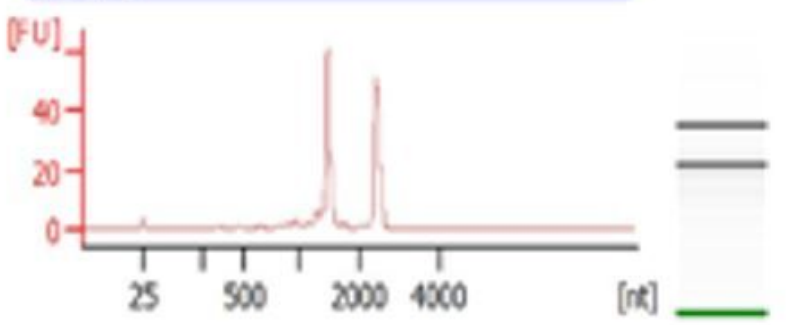

Electropherograms of RNA of B. subtilis TL7-3 under different growth stages using Method 4 during celllysis. 